\title{
SOSIALISASI PRODUK OLAHAN MAKANAN DAN MINUMAN ALAMI SEBAGAI UPAYA PENINGKATAN IMUN DI TENGAH PANDEMI COVID-19 PADA MASYARAKAT KELURAHAN PETOAHA KECAMATAN ABELI KOTA KENDARI SULTRA
}

\author{
Muhammad Zakir Muzakkar ${ }^{1}$, Thamrin Azis ${ }^{1}$, Muh. Nurdin ${ }^{1}$, Maulidiyah ${ }^{1}$, Muh. \\ Natsir ${ }^{1}$, dan Ratna ${ }^{2 *}$ \\ ${ }^{1}$ Jurusan Kimia FMIPA, Universitas Halu Oleo, Kendari, SULTRA, Indonesia \\ ${ }^{2}$ Jurusan Pendidikan Kimia FKIP, Universitas Halu Oleo, Kendari, SULTRA, Indonesia
}

*Email: sitti.ratna@yahoo.com

\begin{abstract}
Natural food and beverage processing is the result of natural food processing sourced from family plants which are usually grown in the yard around the house. Natural processed food and beverage products are not only nutritious and nutritional enhancer but also as cooking spices that contain high antioxidants. Utilization of natural processed food and beverage products as an effort to prevent disease, health care during public health emergencies and especially during the national disaster for the corona virus disease 2019 (COVID-19). The socialization of natural processed food and beverage products is carried out in three stages. The first stage is to prepare and select the types of medicinal plants that are often planted by the Petoaha community around the house. The second stage is material education about the benefits of family medicinal plants (TOGA), processed natural food and beverage products, as an effort to increase immunity in the midst of the COVID-19 pandemic. While the last stage is to provide an explanation of how to process food and beverage ingredients and to clarify the use of natural food and beverage processed products as health care, increase immunity and disease prevention during the COVID-19 pandemic. The result of this activity is to increase the knowledge, insight and awareness of the Petoaha community about the importance of planting TOGA plants and their processed food or beverage products to increase immunity during the Covid 19 pandemic..
\end{abstract}

Keywords: Medicinal plants, immune, Covid 19 pandemic, natural foods and beverages

\section{Abstrak}

Pengolahan makanan dan minuman alami merupakan hasil olahan pangan alami yang bersumber dari tanaman keluarga yang biasanya ditanam di pekarangan sekitar rumah. Produk makanan dan minuman olahan alami tidak hanya berkhasiat dan penambah gizi tetapi juga sebagai bumbu masak yang mengandung antioksidan yang tinggi. Pemanfaatan produk olahan makanan dan minuman alami sebagai upaya pencegahan penyakit, pemeliharaan kesehatan pada saat keadaan darurat kesehatan masyarakat dan khususnya pada saat bencana nasional penyakit virus corona 2019 (COVID 19). Sosialisasi produk olahan makanan dan minuman alami dilakukan dalam tiga tahap. Tahap pertama yaitu menyiapkan dan menyeleksi jenis tanaman obat yang sering ditanam masyarakat Petoaha di sekitar rumah. Tahap kedua adalah edukasi materi tentang manfaat tanaman obat keluarga (TOGA), olahan produk makanan dan minuman alamiah, sebagai upaya peningkatan imunitas di tengah pandemi COVID-19. Sedangkan tahap terakhir yaitu memberikan penjelasan tentang cara mengolah bahan makanan dan minuman serta memperjelas penggunaan produk olahan makanan dan minuman alami sebagai perawatan kesehatan, peningkatan immun dan pencegahan penyakit selama pandemi covid 19. Hasil dari kegiatan ini adalah untuk meningkatkan pengetahuan, wawasan dan kesadaran masyarakat Petoaha tentang pentingnya menanam tanaman TOGA dan produk olahan makanan atau minumannya guna meningkatkan imun pada saat pandemi Covid 19.

Kata Kunci: TOGA, immun, pandemik Covid 19, makanan alami, minuman alami. 


\section{PENDAHULUAN}

Ada dua kelompok masyarakat yang menghuni kelurahan petoaha yaitu petoaha darat dan petoaha pantai. Masyarakat petoaha darat yang umumnya dihuni oleh suku tolaki (pribumi-petani) sedangkan petoaha pantai umumnya dihuni oleh suku bajo (pelaut-nelayan). Pendidikan dan kesejahteraan di Petoaha masih minim khususnya di Petoaha pantai sehingga menjadi perhatian khusus pemerintah Kota Kendari. Sekarang ini tidak cukup hanya perhatian dan bimbingan semua pihak tetapi bantuan dana yang terkontrol sangat diharapkan untuk meningkatkan harkat dan martabat masyarakat Petoaha terkhusus dalam masa pandemi Covid-19 (Balaka \& Putri, 2019). Kehidupan sederhana penduduk Petoaha tidak menghalangi mereka meningkatkan imun dengan memanfaatkan tanaman atau obat tradisional di sekitar pekarangan rumah yang disebut tanaman obat keluarga (TOGA). Tanaman obat tradisional sudah dikenal sejak dahulu kala oleh nenek moyang kita untuk menjaga kesehatan, mempertahankan dan meningkatkan imun serta dapat mengobati penyakit (Parawansah et al., 2020; Yassir \& Meliyana, 2019). Adapun tanaman obat keluarga yang sering ditanam sekitar rumah diantaranya jahe, tomat, kunyit, kencur, kunyit putih, daun sereh, daun kelor, labu, lidah buaya, jambu biji, jeruk nipis, mentimun, bayam dan lain-lain. Kesemua tanaman TOGA tersebut mengandung zat antioksidan yang tinggi. Zat antioksidan merupakan zat yang sangat bermanfaat bagi kesehatan dan kekebalan tubuh sebab kemampuannya menangkap radikal-radikal bebas yang banyak terbentuk dalam tubuh. Radikal bebas dalam tubuh berpotensi merusak sel-sel karena bersifat oksidator kuat sehingga lambat laun akan terjadi kerusakan pada jaringan dan organ (Dewi \& Riyandari, 2020; Tahril et al., 2019; Wabula et al., 2019; Yassir \& Meliyana, 2019).

\begin{tabular}{lrr}
\multicolumn{2}{c}{ Selama pandemi } & Covid-19 \\
dimerata dunia banyak & kebijakan \\
pemerintah dan para & ilmuan
\end{tabular}
bermunculan untuk melawan pandemi yang sangat serius diantaranya dengan; (i) lock down (Yunus \& Rezki, 2020), (ii) pembatasan sosial berskala besar (PSBB) dengan cara menjaga jarak, memakai masker dan mencuci tangan (3M) (Burhan et al., 2020), (iii) menjaga dan meningkatkan imun tubuh (Syamson, 2019), (iv) olahraga (Syahruddin, 2020), (v) meningkatkan keimanan dan ketaqwaan (Butar-Butar, 2014). Jika diteliti secara saksama maka kelima kebijakan di atas semua ada benarnya tetapi pemerintah akan memilih kebijakan yang terbaik untuk masyarakatnya. Setiap Negara atau daerah berbeda-beda kebijakannya misalnya Indonesia menerapkan PSBB.

Sejak manusia lahir di muka bumi, maka dengan sendirinya tubuh membentuk system pertahanan tubuh (imun) atau kekebalan tubuh secara alami. Kemampuan tubuh untuk menahan dan melawan segala macam serangan penyakit, serangan benda asing yang berpotensi merugikan tubuh, dan 
rusaknya sel-sel tubuh disebut imunitas atau kekebalan tubuh (Izazi \& Kusuma, 2020; Li et al., 2020; Susilo et al., 2020; Zhang et al., 2020). Faktor yang mempengaruhi sistem imun diantaranya genetik, fisiologis, stress, usia, hormon, olahraga, nutrisi yang tidak terpenuhi, dan terpaparnya zat yang berbahaya misalnya zat radioaktif, pestisida dan bahan kimia. Imunitas yang rendah pada manusia akan menyebabkan mudahnya terpapar penyakit atau virus khususnya virus Covid-19 (Amalia \& Hiola, 2020; Izazi \& Kusuma, 2020; Tahril et al., 2020). Sampai saat ini penanganan virus ini tergantung dari pola masing masing individu baik pola hidup ataupun pola kesehatan.

Membangun dan meningkatkan kekebalan tubuh (sistem imun) dapat dilakukan dengan menjaga asupan gizi dalam makanan, terutama makanan atau minuman yang mengandung vitamin, mineral, dan antioksidan. Makanan atau minuman yang mengandung vitamin, mineral dan antioksidan dapat diperoleh melalui makanan yang bersumber dari hewan ataupun tanaman (Dimyati et al., 2020; Riwal et al., 2019; Sumarni et al., 2017). Karena pentingnya program ini, maka telah melaksanakan sosialisasi dan edukasi tetang produk olahan makanan dan minuman alami dengan kandungan antioksidan tinggi kepada masyarakat Petoaha berbasis tanaman obat keluarga (TOGA).

\section{TINJAUAN LITERATUR}

Tanaman TOGA yang akan digunakan pada program sosialisasi produk olahan makanan dan minuman alami yang perlu dikonsumsi sebagai makanan tambahan pada masa pandemi dapat dilihat pada Tabel 1 .

Tabel 1. Beberapa jenis tanaman TOGA yang sering ditanam masyarakat Petoaha di sekitar lingkungan rumah (Pujiastuti \& Kristiani, 2019; Widyanata et al., 2020)

\begin{tabular}{llll}
\hline No. & Nama Tanaman & $\begin{array}{c}\text { Bagian Yang } \\
\text { Digunakan }\end{array}$ & $\begin{array}{c}\text { Kandungan Zat } \\
\text { Aktif }\end{array}$ \\
\hline 1 & Jahe (Zingiber officinale) & Rimpang & $\begin{array}{l}\text { Gingerol dan } \\
\text { shogaol }\end{array}$ \\
& & & \\
& & & \\
\hline 2 & Jambu biji (Psidium guajava) & Buah & $\begin{array}{l}\text { Vitamin C, } \\
\text { flavonid, } \\
\text { guaijavarin dan } \\
\text { quercetin }\end{array}$ \\
& & & \\
& & & \\
\hline
\end{tabular}




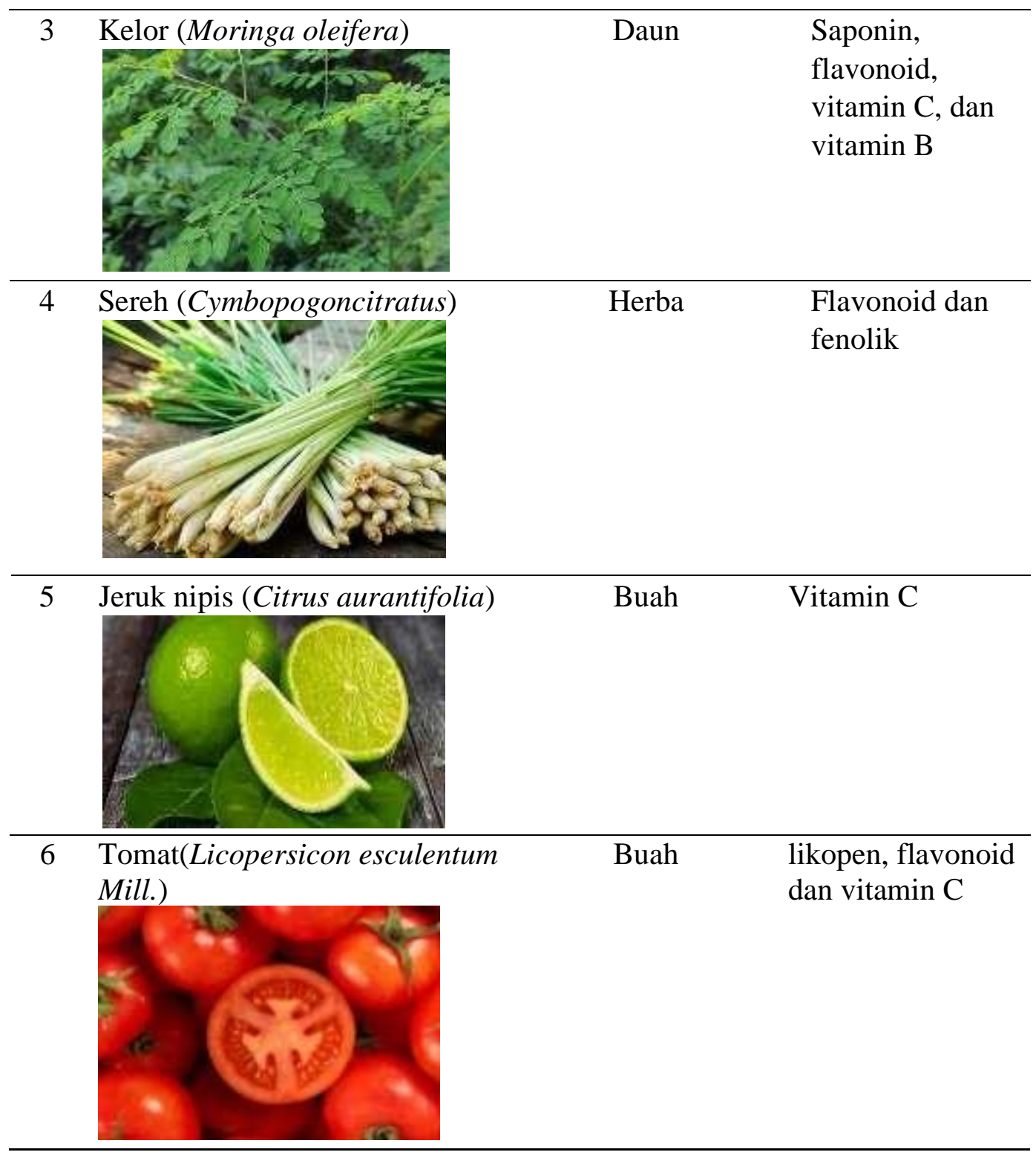

Jahe (Zingiber officinale), merupakan tanaman rempah yang berasal dari Asia Selatan, dan sekarang telah tersebar ke seluruh dunia. Zat-zat aktif dalam minyak atsiri jahe, antara lain: shogaol, gingerol, zingeron, dan zat-zat antioksidan alami lainnya memiliki khasiat untuk mencegah dan mengobati berbagai penyakit dari yang ringan sampai berat, seperti: masuk angin, batuk, kepala pusing, pegal-pegal, rematik, mualmual, mabuk perjalanan, impoten, Alzheimer, kanker, dan penyakit jantung (Aryanta, 2019).
Jambu biji (Psidium guajava), berasal dari Amerika tropik, tumbuh pada tanah yang gembur maupun liat, pada tempat terbuka dan mengandung air yang cukup banyak. Buah jambu biji mengandung berbagai zat yang berfungsi sebagai penghambat berbagai jenis penyakit, diantaranya; flavonoid, tanin, minyak atsiri, vitamin $\mathrm{C}$, guaijavarin dan quercetin dan saponin. Buah jambu biji digunakan untuk pengobatan kencing manis (diabetes melitus), kadar kolesterol, darah tinggi 
(hiperkolesterolmia) dan sembelit (Hasanalita et al., 2019).

Tanaman kelor (Moringa oleifera Lam) telah dikenal selama berabad-abad sebagai tanaman multiguna padat nutrisi dan berkhasiat obat. Kelor dikenal sebagai The Miracle Tree atau pohon ajaib karena terbukti secara alamiah merupakan sumber gizi berkhasiat obat yang kandungannya di luar kebiasaan kandungan tanaman pada umumnya. berbagai bagian dari tanaman kelor bertindak sebagai stimulan jantung dan peredaran darah, memiliki antitumor, antipiretik, antiepilepsi, antiinflamasi, antiulcer, diuretik, antihipertensi, menurunkan kolesterol, antioksidan, antidiabetik, antibakteri dan antijamur (Toripah, 2014).

Tanaman

(Cymbopogoncitratus) tanaman herba menahun tergolong dalam jenis rumput rumputan. Tanaman sereh dalam pemanfaatannya memiliki tiga bagian yang penting yaitu akar, batang dan daun. Akar biasanya digunakan sebagai obat tradisional, batang banyak mengandung minyak atsiri sehingga sering digunakan sebagai bumbu dapur dan aroma (Yuliningtyas et al., 2019) Jeruk nipis (Citrus aurantifolia), merupakan sejenis tanaman perdu yang banyak tumbuh di Indonesia. Buah jeruk nipis mengandung banyak senyawa kimia yang bermanfaat seperti asam sitrat, asam amino (triptopan dan lisin), minyak atsiri (limonen, linalin asetat, geranil asetat, fellandren, sitral, lemon kamfer, kadinen, aktialdehid, anildehid), vitamin A, B1 dan vitamin C. Hasil penelitian para pakar menyebutkan bahwa buah jeruk nipis berkhasiat sebagai obat berbagai penyakit, juga buah jeruk nipis sering digunakan sebagai bahan dasar kosmetik (Haq et al., 2010).

Buah tomat (Lycopersicum esculentum Mill) adalah buah khas Amerika. Tomat tergolong buah karena merupakan bagian tanaman yang bisa dimakan, yang mengandung biji atau benih. penyakit yang baik bagi kesehatan, terutama likopen. Tomat mengandung lemak dan kalori dalam jumlah rendah, bebas kolesterol, dan merupakan sumber serat dan protein yang baik. Selain itu, tomat kaya akan vitamin $\mathrm{A}$ dan $\mathrm{C}$, beta-karoten, kalium dan antioksidan likopen (Kailaku \& Dewandari, 2018).

Keenam tanaman obat keluarga tersebut telah disosialisasikan kepada warga kelurahan Petoaha untuk menambah pengetahuan, wawasan dan kesadaran pentingnya tanaman ini selalu ada hidup di pekarangan rumah. Juga disosialisasikan cara mengolah makanan dan minuman alami berbasis tanaman obat keluarga.

\section{METODE PELAKSANAAN}

Metode pelaksaan yang dilakukan dalam program sosialisasi produk olahan makanan dan minuman alami berbasis tanaman obat keluarga (TOGA) ini dibagi menjadi tiga tahapan. Tahap pertama yaitu menyiapkan dan menyeleksi jenis tanaman obat yang sering ditanam masyarakat Petoaha di sekitar rumah. Tahap kedua adalah edukasi materi tentang manfaat tanaman obat keluarga (TOGA), olahan produk makanan dan minuman alamiah, sebagai upaya peningkatan imunitas di tengah pandemi COVID-19. Sedangkan tahap terakhir yaitu memberikan penjelasan dan peragaan secara daring tentang cara 
mengolah bahan makanan dan minuman serta memperjelas penggunaan produk olahan makanan dan minuman alami sebagai perawatan kesehatan, peningkatan immun dan pencegahan penyakit pada pandemi covid 19. Adapun tanaman obat keluarga yang kami pilih dalam sosialisasi ini adalah jahe, jambu biji, daun kelor, daun sereh, jeruk nipis dan tomat.

Kegiatan pengabdian kepada masyarakat, melibatkan seluruh elemen masyarakat secara bersama-sama, bersinergi, dan multidisiplin. Kegiatan ini bertujuan agar dapat meningkatkan pengetahuan dan wawasan masyarakat Petoaha akan pentingnya produk pengolahan makanan dan minuman alami berbasis Tanaman Obat Keluarga (TOGA) dalam upaya untuk meningkatkan imunitas tubuh ditengah pandemi covid 19.

\section{HASIL DAN PEMBAHASAN}

Pengabdian dilaksanakan dengan melibatkan mahasiswa KKN tematik Covid-19.

Jumlah mahasiswa KKN tematik sebanyak sepuluh (10) yang kesemuanya dari Fakultas MIPA UHO. Pelaksanaan pengabdian mengikuti protokol covid-19 (PSBB) sehingga seluruh kegiatan pengabdian dilaksanakan secara daring (online). Lokasi pengabdian adalah Kelurahan Petoaha, Kecamatan Abeli, Kota Kendari Sulawesi Tenggara (SULTRA).

Pelaksanaan pengabdian KKN tematik terbagi empat tahap. (i) Pertama, pelepasan KKN tematik UHO 2020 oleh rector UHO, (ii) kedua, pembekalan mahasiswa oleh dosen pembimbing lapangan sebelum berinteraksi dengan masyarakat kelurahan Petoaha, (iii) ketiga, pelaksanaan pengabdian KKN Tematik UHO 2020, dan (iv) keempat, penarikan KKN Tematik. Pertanggung jawaban daripada KKN tematik ini adalah pelaporan baik mahasiswa maupun dosen pembimbing.

Pelepasan KKN tematik UHO 2020 di lakukan secara virtual dengan menggunakan aplikasi Zoom Meeting dan Youtube pada Jum'at, 12 Juni 2020 Pukul 13.00 WITA. Upacara pelepasan tersebut dihadiri oleh seluruh Dosen Pembimbing Lapangan (DPL) KKNTematik dari tiap-tiap Fakultas selain itu Pelepasan ini secara simbolis dipimpin oleh Rektor Universitas Halu Oleo Prof. Dr. Muhammad Zamrun, M.Si., M.Sc dan Ketua LPPM Universitas Halu Oleo Dr. H. La Aba, S.Si., M.Si. (Gambar 1) 


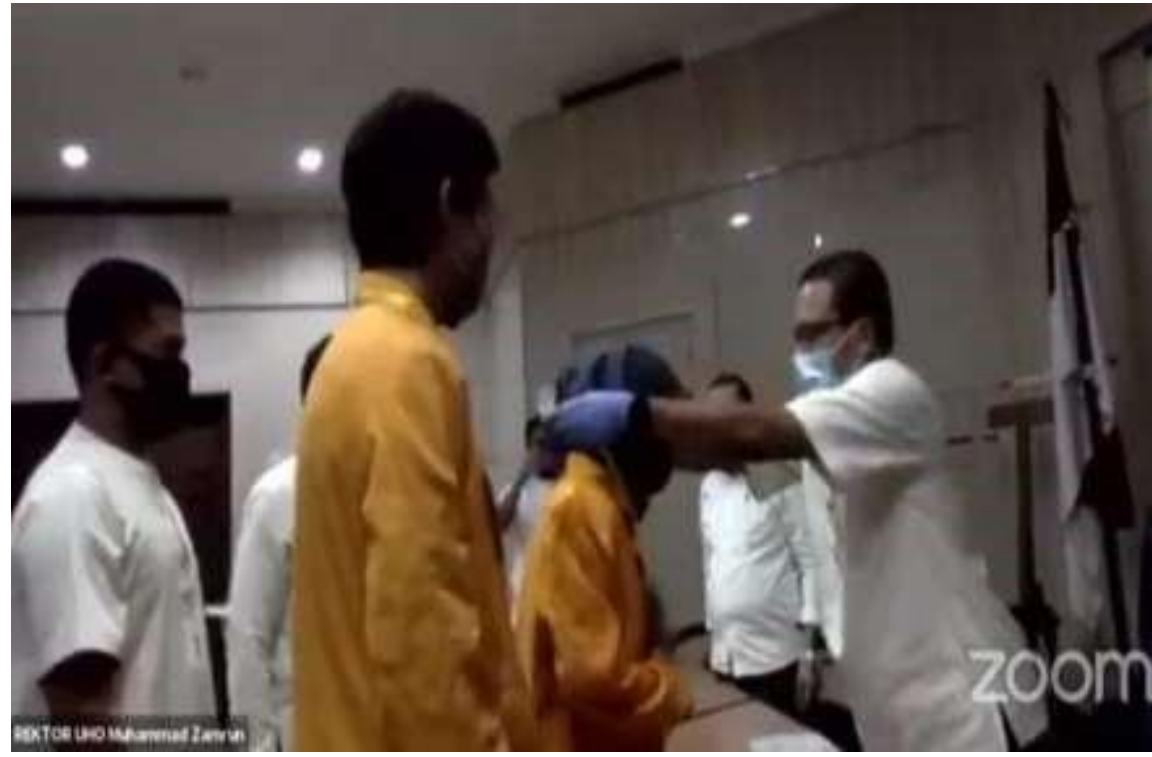

Gambar 1. Pelepasan KKN Tematik UHO 2020 secara simbolik oleh Rektor Universitas Halu Oleo (UHO), Prof. Dr. Muhammad Zamrun, M.Si., M.Sc.

Pembekalan mahasiswa KKN Pembekalan ini berlangsung pada oleh dosen pembimbing lapangan (DPL). Pembekalan disampaikan oleh dosen pembimbing lapangan kepada 10 orang mahasiswa peserta KKN Tematik. tanggal 14 Juni 2020 yang di lakukan secara virtual dengan menggunakan aplikasi zoom meeting (Gambar 2).
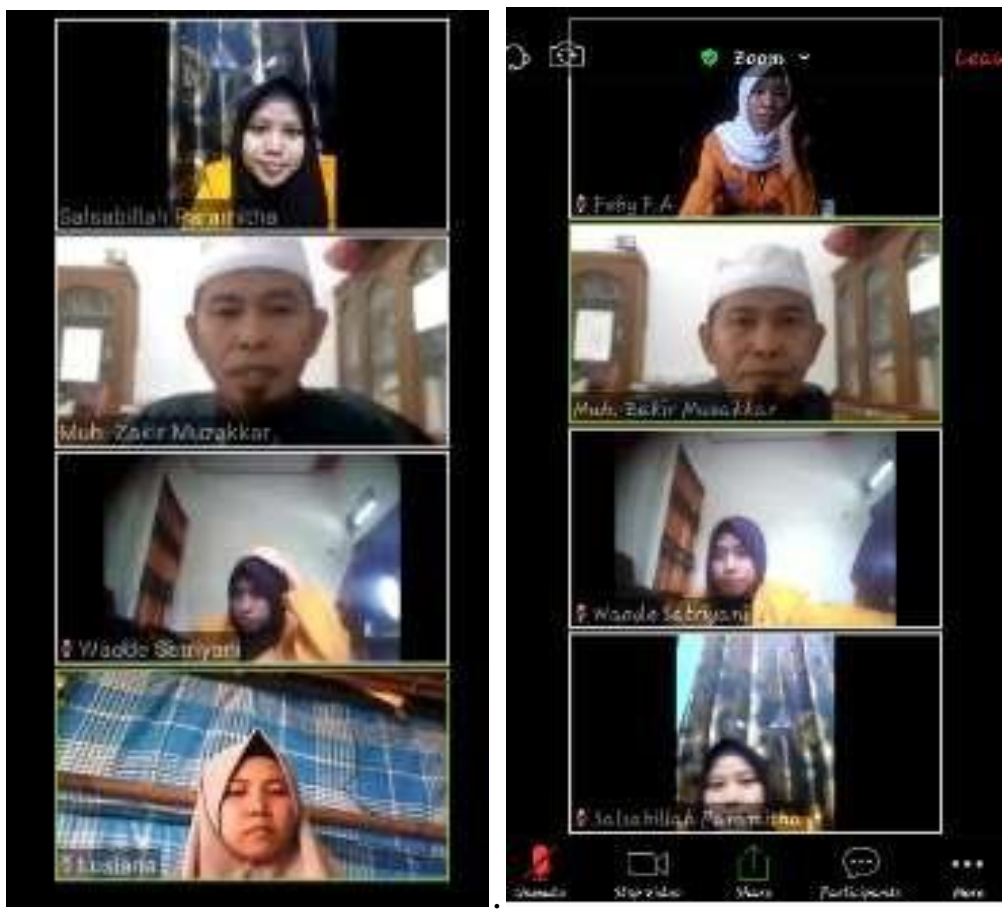

Gambar 2. Pembekalan Peserta KKN Tematik oleh Dosen Pembimbing Lapangan 


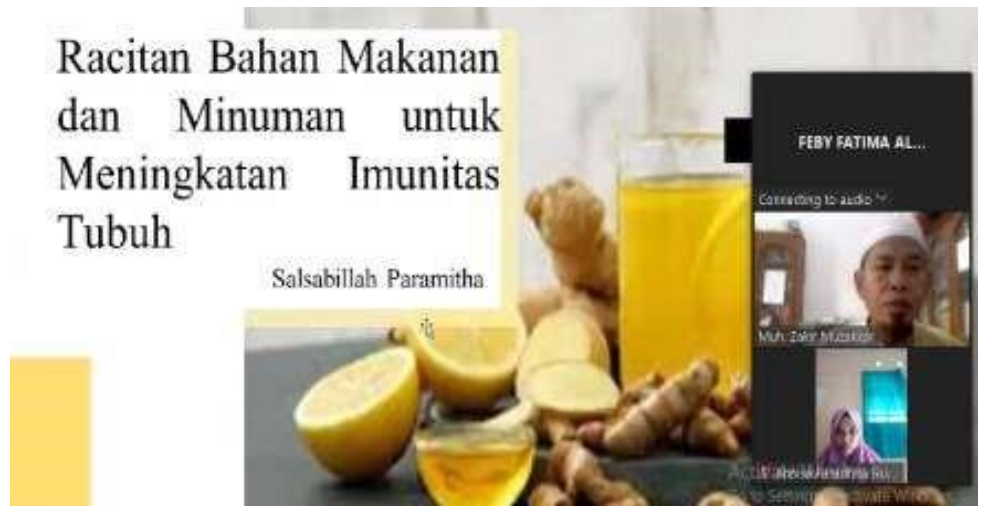

Gambar 3. Sosialisasi produk olahan minuman alami berbasis tanaman obat keluarga (minuman jahe-jeruk nipis)

Pelaksanaan pengabdian KKN Tematik UHO 2020 dibagi dua program. Program pertama adalah sosialisasi pentingnya menanam tanaman obat di pekarangan rumah sebagai tanaman hias tetapi berhasiat. Tanaman yang kami tampilkan dalam sosialisasi adalah tanaman yang dipercaya kaya akan zat antioksidan (lihat Table 1). Tujuan dari program sosialisasi Tanaman Obat Keluarga (TOGA) adalah untuk meningkatkan pengetahuan, wawasan dan kesadaran masyarakat mengenai pentingnya menyiapkan tanaman obat keluarga di pekarangan rumah guna meningkatkan kekebalan tubuh di tengah pandemi Covid 19. Oleh karena itu kegiatan ini sangat perlu dilakukan mengingat semakin meningkatnya kasus yang terkonfirmasi positif Covid 19 di Kota Kendari.

Program kedua adalah sosialisasi olahan makanan dan minuman alami berbasis tanaman obat keluarga. Olahan makanan dan minuman alami yang djelaskan pada sosialisasi ini adalah jahe, jambu biji, daun kelor, daun sereh, jeruk nipis dan tomat. Semua tanaman yang disosialisasikan ini dapat meningkatkan imunitas tubuh (Gambar 3 dan 4).

\section{Cara membuat}
- Kupas kulit bawang dan rajang, iris $^{2}$ cabe merah, daun kelornya di preteli dan cuci bersih, campurkan semua bahan kedalam telur, kocok, beri garam secukup
- Goreng dengan minyak yang sudah dipanaskan. Minyaknya sedikit saja yaahhhh.

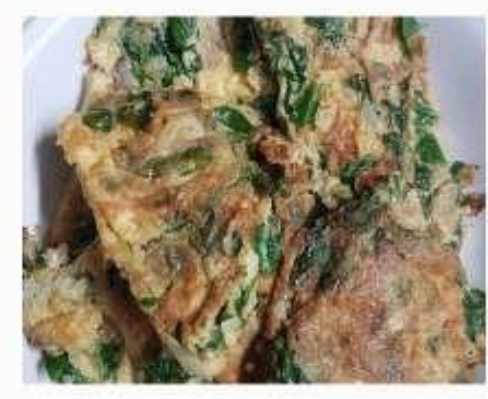

Gambar 4. Presentasi mahasiswa KKN Tematik UHO 2020 berupa produk olahan dadar telur berbasis daun kelor 
Semua proses pengabdian dapat berjalan sebagaimana yang diharapkan dimana peserta yang hadir diberi kesempatan untuk bertanya sehinga terjadi diskusi interaktif secara online antara pemateri dengan seluruh masyarakat yang hadir. Betapa antusiasnya warga Kelurahan Petoaha sehingga mereka sangat mengharapkan kedatangan kami dengan kegiatan lanjutan atau kegiatan lain.

\section{PENUTUP}

Berdasarkan dari hasil uraian, tanaman obat keluarga adalah tanaman berkhasiat yang ditanam di lahan pekarangan yang dikelola oleh keluarga yang dimanfaatkan dalam upaya peningkatan kesehatan baik dalam upaya preventif, promotif dan kuratif. Produk olahan makanan dan minuman alami berbasis tanaman obat sebagai makanan tambahan sangat perlu untuk disosialisasikan kepada masyarakat untuk mendapatkan perawatan kesehatan yang murah meriah bertujuan meningkatkan imunitas tubuh terutama dalam masa kedaruratan kesehatan masyarakat dan dalam masa pandemi COVID-19 saat ini. Kegiatan ini sangat bermanfaat bagi masyarakat sehingga dapat meningkatkan pengetahuan, wawasan dan kesadaran masyarakat akan pentingnya pemanfaatan Tanaman Obat Keluarga untuk meningkatkan imunitas tubuh di masa pandemi saat ini. Dari hasil pemantauan tanaman TOGA di pekarangan masyarakat Petoaha masih minim, maka sangat perlu diadakan sosialisasi dan edukasi tentang pentingnya menanam tanaman obat keluarga di pekarangan rumah.

\section{DAFTAR PUSTAKA}

Amalia, L., \& Hiola, F. 2020. Analisis Gejala Klinis Dan Peningkatan Kekebalan Tubuh Untuk Mencegah Penyakit Covid-19. Jambura Journal of Health Sciences and Research, 2(2), 7176.

Aryanta, I. W. R. 2019. Manfaat Jahe Untuk Kesehatan. Widya Kesehatan, 1(2), 39-43.

Balaka, R., \& Putri, T. S. 2019. Gambaran Sanitasi Pemukiman Di Daerah Pesisir (Studi Kasus: Pemukiman Pesisir di Kelurahan Petoaha, Kota Kendari). STABILITA Jurnal Ilmiah Teknik Sipil, 7(2), 167-172.

Burhan, E., Susanto, A. D., Nasution, S. A., Ginanjar, E., Pitoyo, C. W., Susilo, A., Firdaus, I., Anwar, Santoso, Juzar, D. A., Arif, S. K., Lolong, N. G. H., Wulung, Damayanti, T., Wiyono, W. H., Prasenohadi, Afiatin, Wahyudi, E. R., Tarigan, T. J. E., Hidayat, R., Faisal, \& Muchtar. 2020. Protokol Tatalaksana Covid-19. Jakarta: Ikatan Dokter Anak Indonesia (IDAI).

Butar-Butar, A. J. R. 2014. Deskripsi dan Anotasi Singkat ManuskripManuskrip Wabah, Pandemi, dan Penyakit Menular.

Dewi, Y. K., \& Riyandari, B. A. 2020. Potensi Tanaman Lokal sebagai Tanaman Obat dalam Menghambat Penyebaran COVID19. Jurnal Pharmascience, 7(2), 112-128.

Dimyati, K. K. H., Muzakkar, M. Z., \& Hermanto, H. 2020. Pengaruh Konsentrasi Penambahan Gum Arab Terhadap Karakteristik Organoleptik Dan Kimia Fruit 
Leather Pisang Raja (Musa paradisiaca Var. raja). Jurnal Sains dan Teknologi Pangan, 5(1), 27532765.

Haq, G. I., Permanasari, A., \& Sholihin, H. 2010. Efektivitas penggunaan sari buah jeruk nipis terhadap ketahanan nasi. Jurnal Sains dan Teknologi Kimia, 1(1), 4458.

Hasanalita, H., Amir, A., \& Defrin, D. 2019. Efektifitas Ekstrak Jambu Biji Terhadap

Kadar Hemoglobin Pada Tikus Bunting. Jurnal Kesehatan Andalas, 8(2), 290294.

Izazi, F., \& Kusuma, A. 2020. Hasil Responden Pengetahuan Masyarakat Terhadap Cara Pengolahan Temulawak (Curcuma Xanthorrhiza) dan Kencur (Kaemferia galanga) Sebagai Peningkatan Imunitas Selama COVID-19 dengan Menggunakan Kedekatan Konsep Program Leximancer. Journal of Pharmacy and Science, 5(2), 93-97.

Kailaku, S. I., \& Dewandari, K. T. 2018. Potensi likopen dalam tomat untuk kesehatan.

Li, X., Geng, M., Peng, Y., Meng, L., \& Lu, S. 2020. Molecular immune pathogenesis and diagnosis of COVID-19. Journal of Pharmaceutical Analysis.

Parawansah, P., Esso, A., \& Saida, S. 2020. Sosialisasi Pemanfaatan Tanaman Obat Keluarga Sebagai Upaya Untuk Meningkatkan Imunitas Tubuh Ditengah Pandemi di Kota Kendari. Journal of Community Engagement in Health, 3(2), 325-328.

Pujiastuti, A., \& Kristiani, M. 2019. Formulasi dan uji stabilitas mekanik hand and body lotion sari buah tomat (Licopersicon esculentum Mill.) sebagai antioksidan. Jurnal Farmasi Indonesia, 16(1), 42-55.

Riwal, R., Muzakkar, M. Z., \& Hermanto, H. 2019. Pengaruh Penambahan Hidrokoloid Carboxyl Methyl Cellulose (CMC) Terhadap Karakteristik Organoleptik Dan Kimia Selai Dari Buah Pisang Mas (Musa acuminata colla). Jurnal Sains dan Teknologi Pangan, 4(6), 26352646.

Sumarni, S., Muzakkar, M. Z., \& Tamrin, T. 2017. Pengaruh Penambahan CMC (Carboxy Methyl Cellulose) Terhadap Karakteristik Organoleptik, Nilai Gizi dan Sifat Fisik Susu Ketapang (Terminallia catappaL.). Jurnal Sains dan Teknologi Pangan, 2(3), 604-614.

Susilo, A., Rumende, C. M., Pitoyo, C. W., Santoso, W. D., Yulianti, M., Herikurniawan, H., Sinto, R., Singh, G., Nainggolan, L., \& Nelwan, E. J. 2020. Coronavirus Disease 2019: Tinjauan Literatur Terkini. Jurnal Penyakit Dalam Indonesia, 7(1), 45-67.

Syahruddin, S. 2020. Kebugaran Jasmani Bagi Lansia Saat Pandemi Covid-19. JUARA: Jurnal Olahraga, 5(2), 232-239.

Syamson, M. M. 2019. Penyuluhan Dalam Pemanfaatan Tanaman Obat Keluarga (TOGA). Jurnal Kesehatan Lentera Acitya, 6(2).

Tahril, Paulina Taba, Nursiah La Nafie, Alfian Noor, Ratna, \& Muzakkar, M. Z. 2020. Iron, Manganese and Copper Metals in Seagrass Ecology in Donggala District, Indonesia. Asian Journal of 
Applied Sciences, 13(1), 1-7. doi:10.3923/ajaps.2020.1.7

Tahril, Taba, P., Nafie, N. L., Noor, A., Ratna, \& Muzakkar, M. Z., 2019. Fatty acid map of various species seagrasses on the Donggala Beach. Paper presented at the IOP Conference Series: Earth and Environmental Science, Kolaka Indonesia, 382(1), 012018. doi:10.1088/17551315/382/1/012018.

Toripah, S. S. 2014. Aktivitas Antioksidan Dan Kandungan Total Fenolik Ekstrak Daun Kelor (Moringa oleifera LAM). Pharmacon, 3(4).

Wabula, R. A., Dali, S., \& Widiastuti, H. 2019. Aktivitas Antioksidan Ekstrak Etanol Buah Merah (Pandanus conoideus Lam.) dengan Metode FRAP. Window of Health: Jurnal Kesehatan, 329337.

Widyanata, K. a. J., Mayadewi, N. N. A., Cahyaningrum, P. L., Trarintya, M. a. P., Muryani, N. M. S., Daryaswanti, P. I., Artawan, I. K., Pendet, N. M. D. P., \& Putra, I. G. Y. 2020. PemanfaatanTanaman Obat Keluarga (TOGA) di Masa
Pandemi COVID-19. Jayapangus Press Books, i-32.

Yassir, M., \& Meliyana, M. 2019. Jenis Tanaman Obat di Kecamatan Semadam

Kabupaten Aceh Tenggara. Serambi Saintia: Jurnal Sains dan Aplikasi, 7(1), 612.

Yuliningtyas, A. W., Santoso, H., \& Syauqi, A. 2019. Uji Kandungan Senyawa Aktif Minuman Jahe Sereh (Zingiber officinale dan Cymbopogon citratus). BIOSAINTROPIS (BIOSCIENCE-TROPIC), 4(2), 16.

Yunus, N. R., \& Rezki, A. 2020. Kebijakan Pemberlakuan Lock Down Sebagai Antisipasi Penyebaran Corona Virus Covid19. Salam: Jurnal Sosial dan Budaya Syar-i, 7(3), 227-238.

Zhang, B., Zhou, X., Zhu, C., Song, Y., Feng, F., Qiu, Y., Feng, J., Jia, Q., Song, Q., \& Zhu, B. 2020. Immune phenotyping based on the neutrophil-to-lymphocyte ratio and IgG level predicts disease severity and outcome for patients with COVID-19. Frontiers in molecular biosciences, 7, 157. 